\title{
Antibacterial Activity Test of Ethanol Extract and SAP of Betung Bamboo Shoot (Dendrocalamus asper) Against Klebsiella pneumoniae and Pseudomonas aeruginosa Bacteria
}

\author{
Anif Nur Artanti* and Farikatul Sufi Mujahidah \\ Department of Pharmacy, Faculty of Mathematics and Natural Science, Universitas Sebelas Maret, J1. Ir. Sutami \\ 36A Kentingan Jebres Surakarta 57126, Indonesia \\ *Corresponding author: antantinuranif@gmail.com
}

\begin{abstract}
Boiled water from bamboo shoots is often used for pneumonia and a cleanser for the wound. It is known that bamboo can be an antibacterial agent because it has saponin, alkaloid, and flavonoid. This research aims to study whether ethanol extract and sap from bamboo betung shoot (Dendrocalamus asper) has secondary metabolism and antibacterial activity against Klebsiella pneumoniae and Pseudomonas aeruginosa. The extract was taken by maceration method using ethanol $96 \%$, and the sap was taken from the water of bamboo shoot. Antibacterial activity test was conducted using disc diffusion method to measure the magnitude of inhibitory power at six concentration ratios of $\mathrm{b} / \mathrm{v}$ solutions $(10 \% ; 20 \% ; 30 \% ; 40 \% ; 50 \% ; 60 \%)$. The result showed that ethanol extract and sap of bamboo betung shoot contained saponin, quercetin, and quinine which were supposed to have antibacterial activity against Klebsiella pneumoniae and Pseudomonas aeruginosa. The largest inhibitory zone diameter was found in ethanol extract $60 \%$ with the category of moderate inhibition of $9.05 \pm 0.12 \mathrm{~mm}$ against Kliebsiella pneumoniae and $5.07 \pm 0.13 \mathrm{~mm}$ against Pseudomonas aeruginosa. While the sap with a concentration of $60 \%$ was included in the weak inhibitory category, which was $5.65 \pm 0.05 \mathrm{~mm}$ in the Kliebsiella pneumoniae and $4.81 \pm 0.22 \mathrm{~mm}$ in Pseudomonas aeruginosa.
\end{abstract}

Keywords: antibacterial; bamboo shoot; betung bamboo.

Cite this as: Artanti, A. N., and Mujahidah, F. S. (2021). Antibacterial Activity Test of Ethanol Extract and SAP of Betung Bamboo Shoot (Dendrocalamus asper) Against Klebsiella pneumoniae and Pseudomonas aeruginosa Bacteria. Journal of Biodiversity and Biotechnology. 1(1), 11-16. doi: http://dx.doi.org/10.20961/jbb.v1i1.50519.

\section{Introduction}

Klebsiella pneumoniae is a gramnegative opportunistic pathogenic bacteria that can cause respiratory infections, urinary tract infections, nosocomial infections, and even death by up to $10 \%$ in humans (1). Pseudomonas aeruginosa is a gram-negative bacteria that can cause infections in wounds and burns that cause bluish-green pus, urinary tract infections, respiratory infections that cause pneumonia, mild external muscularity in swimmers, and eye infections (2). Both of these bacteria can be found in most human environments (3).

The boiled water from bamboo shoots is used to treat coughing up blood (pneumonia) and is used as a wound cleanser (4). Bamboo shoots have excellent antioxidant, anti-freeradical, and anti-aging effects because of flavones and glycosides (5). Betung bamboo leaves (Dendrocalamus asper) have antibacterial activity against $E$. coli bacteria. All bacteria and fungi grow well in wet media and humid air. Water has a vital role in life because microorganisms can only take food from outside into the solution (holophytic). Bamboo shoots are used as an infection treatment, but bamboo shoots' water content is relatively high. Every 100 grams of fresh bamboo shoots has water content of $91 \%$ (6). The water content of the Schizostachyum brachycladum Kurz bamboo shoot ethanol extract was $9,12 \%$ (7). So far, there has been no test for the antibacterial activity of bamboo 
shoots against Klebsiella pneumoniae and Pseudomonas aeruginosa.

\section{Material and Methods}

This study was taken on Pharmacy Laboratorium and FMIPA Intergrated Laboratory. In this study, the extract was taken by the maceration method using $96 \%$ ethanol, and the sap was taken from the juice of bamboo shoots. Qualitative testing of the chemical content of bamboo betung using thin layer chromatography and tube testing. The antibacterial activity test used the disc diffusion method to measure the amount of inhibition at six concentration ratios of the w/v solution $(10 \% ; 20 \% ; 30 \% ; 40 \% ; 50 \% ; 60 \%)$.

The tools used in this study include a set of maceration tools, blender, flannelette, stirring rod, rotary evaporator (Yamato RE301-AW), UV light $254 \mathrm{~nm}$, test tube (Pyrex), test tube rack, bunsen, sterile cotton swab, petri dish, measuring cup (Pyrex) $25 \mathrm{ml}$, ose needle, 10-100 $\mu 1$ series micropipettes (Master ptt $\AA$ ), bunsen, yellow tip, tweezers, analyte scale, Moisture Analyzer (Ohaous MB23), Laminar Air Flow (Biobase), autoclave (Sturdy®), oven, incubator (Incubator Hotcold- M), refrigerators, and calipers.

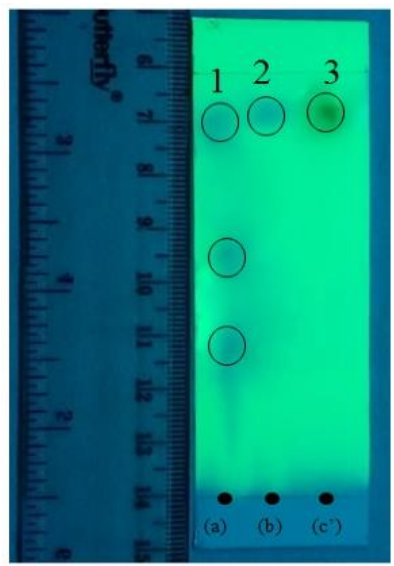

Figure 1. The elution identification of the flavonoid group at $254 \mathrm{~nm}$ UV light with a mobile phase of Butanol: Acetic Acid: Water (4: 1: 5). (a) Betung Bamboo Shoots Ethanol Extract (b) Betung Bamboo Shoots Sap (c) quercetin standard

The materials used in this study included bamboo shoots (Dendrocalamus asper), 96\% alcohol, flannelette, aquadest, filter paper, silica gel 60 F254 (Merck), quercetin standards, quinine standards, butanol, acetic acid, disc paper (Oxioid), aluminum foil, MHA agar media, 0.5 Mac Farland standard, 0.9\% sterile $\mathrm{NaCl}$, Amoxicillin $25 \mu \mathrm{g}$ / disk antibiotic (Oxioid), Kliebsiella pneumoniae bacteria ATCC 13883, and Pseudomonas aeruginosa ATCC 27853.

Identification of ethanol extract compounds and bambu betung saps was done with TLC (Thin Layer Chromatography). The TLC method was used in this study because it has greater flexibility in selecting mobile phases (8). The stationary phase used was a 60 F254 silica gel plate. This plate is used because it can glow at $254 \mathrm{~nm}$ UV light to help visualize spots or stains on the TLC plate (9). While the mobile phase used is a mixture of Butanol: Acetic Acid: Water (4: 1: 5) (10) as shown in Figure 1.

The standard compound used to identify the flavonoid group is quercetin. Quercetin is a class of flavonoids that can be used as antibacterial because quercetin can bind to bacterial DNA gyrase, which plays a role in DNA replication. Quercetin interferes with the gyrase enzyme so that the DNA replication process stops (11). In this study, 6 series of different solution concentrations were made, both ethanol and sap extracts, namely $10 \% \mathrm{w} /$ v, $20 \% \mathrm{w} / \mathrm{v}, 30 \% \mathrm{w} / \mathrm{v}, 40 \% \mathrm{w} / \mathrm{v}, 50 \% \mathrm{w} /$ $\mathrm{v}$, and $60 \%$. b / v.

\section{Results and Discussion}

Characteristics of the extraction results obtained in this study were examined in organoleptic, yield calculations, and water content. The yield determination aims to quantify how much plant extract was obtained (12). A total of 150 grams of betung bamboo shoots macerated with $96 \%$ ethanol yielded 7 grams of the thick extract or around $4.67 \%$. The extract obtained was relatively small because the main component of bamboo shoots was water. This is supported by research from Nofriyati and Ratima (6) that every 100 grams of fresh bamboo shoots contained $91 \%$ water. The characteristics of the ethanol extract of the Betung bamboo shoots can be seen in Table 1 .

Table 1. Characteristics of tunas bambu betung ethanol extract

\begin{tabular}{lll}
\hline Examination & & Result \\
\hline & Consistency & Thick \\
Organoleptic & Color & Brown-yellow \\
& Aroma & Distinctive \\
Extract yield & & $4,67 \%$ \\
Water content & & $28,7 \%$ \\
\hline
\end{tabular}


The water content requirement for an extract, according to Depkes RI (13), is less than $10 \%$. The water content in the extract that was less than $10 \%$; which aimed to avoid the rapid growth of the fungus in the extract (14). Based on the test results, it was found that the water content of the betung bamboo shoots ethanol extract was $28.7 \%$, so that the resulting extract was not used for storage for a long time.

\section{Identification of ethanol extract compounds and bambu betung saps}

This identification test was conducted to qualitatively determine the content of secondary metabolites in the ethanol extract and sap of Betung bamboo shoots. According to Kalita et al (15), bamboo can have antibacterial activity because it has compounds of flavonoids, alkaloids, and saponins. From the results in Table 2, it can be seen that the ethanol extract and the sap of Betung bamboo shoots have quercetin compounds because the $\mathrm{Rf}$ value is the same (0.88). This result confirmed the research of Susilowati et al (10) that the $\mathrm{Rf}$ value of quercetin compounds with the mobile phase of Butanol: Acetic Acid: Water (4: 1:5) is 0.88 . Hence, it is confirmed that the ethanol extract and sap of Betung bamboo shoots positively have quercetin compounds.

Table 2. Results of the calculation of the rf value for the flavonoid group

\begin{tabular}{ll}
\hline Sample & Rf value \\
\hline Tunas Bambu Betung Ethanol & 0.88 \\
Extract & 0.88 \\
Betung Bamboo Shoots Sap & 0.88 \\
Quercetin standar & \\
\hline
\end{tabular}

The identification of alkaloids is shown in Figure 2, the standard compound used was quinine. Quinine can be used as an antibacterial agent because it can interfere with peptidoglycan components in bacterial cells so that the cell wall layer is not formed entirely and causes cell death (16). The ethanol extract of betung bamboo shoots contained quinine compound because the $\mathrm{Rf}$ value was the same as the standard $\mathrm{Rf}$ value, which was 0.63 (Table 3). This confirmed the results of Susilawati et al. (10) that the Rf value of quinine compounds with the mobile phase of Butanol: Acetic Acid: Water (4: 1: 5) was 0.61. In contrast, the sap of bamboo shoots did not have quinine compounds because its $\mathrm{Rf}$ value was not the same as the $\mathrm{Rf}$ value of quinine.

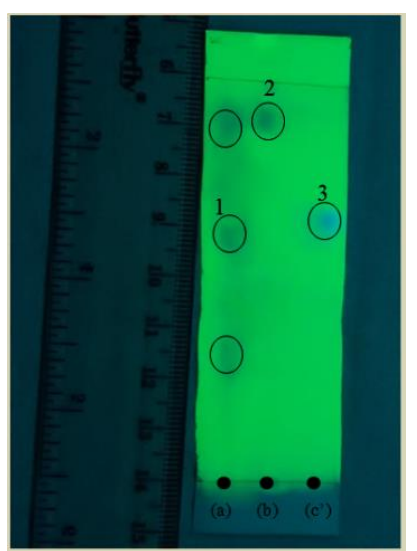

Figure 2. The results of the identification of alkaloids in UV light $254 \mathrm{~nm}$ with mobile phase Butanol: Acetic Acid: Water (4: 1: 5). (a) Betung Bamboo Shoots Ethanol Extract (b) Betung Bamboo Shoots Sap (c) quinine standard

Table 3. Results of the calculation of the $\mathrm{rf}$ value for the alkanoid group

\begin{tabular}{ll}
\hline Sample & Rf value \\
\hline Betung Bamboo Shoots Ethanol & 0.60 \\
Extract & \\
Betung Bamboo Shoots Sap & 0.88 \\
Quinin standar & 0.63 \\
\hline
\end{tabular}

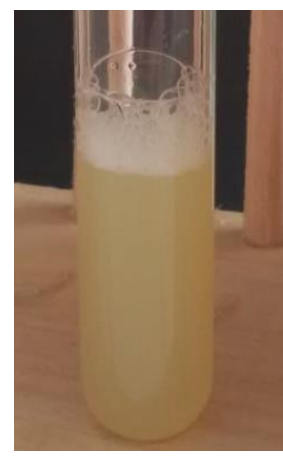

(a)

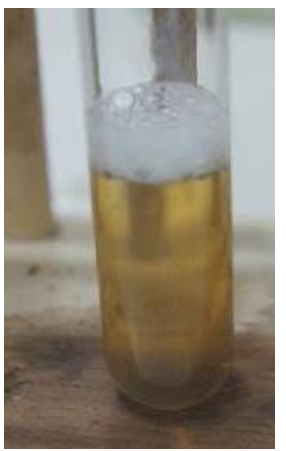

(b)
Figure 3. The results of identification of saponin compounds in the extract and sap of bamboo shoots of Betung bamboo. (a) Betung Bamboo Shoots Ethanol Extract (b) Betung Bamboo Shoots Sap

Saponin identification test was carried out by shuffling. Saponin compounds can be detected because of their ability to form foam. Saponins can damage bacterial cytoplasmic membrane cells by increasing the permeability of bacterial cell membranes (17). Based on the study results shown in Figure 3, there was 1 
$\mathrm{cm}$ foam after being shaken for 15 minutes. Hence, it can be seen that the ethanol extract and sap of Betung bamboo shoots were positive for saponins.

Antibacterial activity test of ethanol extract and saps of betung bamboo shoots

In this study, the antibacterial activity test used the Kirby Bauer or Disc Diffusion method. This method was used because it does not require special equipment. Its implementation was more accessible and more practical, suitable for liquid samples because of the saturation of the sample on disc paper (18).

The positive control used was the amoxicillin antibiotic because amoxicillin is a broad-spectrum antibiotic that works by preventing the synthesis of bacterial cell walls (19). The agar medium used was Mueller Hilton Agar (MHA) because this media was not a selective medium so that all types of bacteria can grow (20).

When viewed from the inhibition zone category according to Davis et al (20), the results of the inhibition zone diameter measurements of the ethanol extract of bamboo shoots against Kliebsiella pneumoniae were in the moderate category; while those in Pseudomonas aeruginosa were in the weak category. Betung bamboo shoot sap has weak inhibitory power against Kliebsiella pneumoniae and Pseudomonas aeruginosa.

Based on the table 4, the largest diameter of the inhibition zone was found in a $60 \%$ concentration solution sample, both in the ethanol extract and sap of the bamboo shoots of Betung. In the $60 \%$ ethanol extract, the inhibition zone diameter was $9.05 \pm 0.12 \mathrm{~mm}$ in Kliebsiella pneumoniae and $5.07 \pm 0.13 \mathrm{~mm}$ in Pseudomonas aeruginosa. While the sap of Betung bamboo shoots with a concentration of $60 \%$ resulted in an inhibition zone diameter of $5.65 \pm 0.05 \mathrm{~mm}$ in Kliebsiella pneumoniae and $4.81 \pm 0.22 \mathrm{~mm}$ in Pseudomonas aeruginosa. Positive control resulted in an inhibition zone diameter of $6.09 \pm 0.03 \mathrm{~mm}$ for Kliebsiella pneumoniae and $5.65 \pm 0.05 \mathrm{~mm}$ for Pseudomonas aeruginosa. The negative control used, namely sterile aquadest, did not show antibacterial activity.

Table 4. Result of inhibition zone diameter measurement

\begin{tabular}{|c|c|c|c|}
\hline \multirow{2}{*}{ Sample } & \multirow{2}{*}{$\begin{array}{l}\text { Concentration } \\
\text { (\%) b/v }\end{array}$} & \multicolumn{2}{|c|}{ Average Inhibition Zone Diameter $*(\mathrm{~mm}) \pm \mathrm{SD}$} \\
\hline & & Kliebsiella pneumoniae & Pseudomonas aeruginosa \\
\hline Betung Bamboo & 10 & $5.43 \pm 0.40$ & 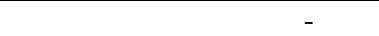 \\
\hline Shoots Ethanol & 20 & $6.36 \pm 0.39$ & $3.16 \pm 0.15$ \\
\hline \multirow[t]{4}{*}{ Extract } & 30 & $6.74 \pm 0.18$ & $3.63 \pm 0.46$ \\
\hline & 40 & $7.13 \pm 0.19$ & $3.46 \pm 0.4$ \\
\hline & 50 & $8.10 \pm 0.13$ & $4.21 \pm 0.21$ \\
\hline & 60 & $9.05 \pm 0.12$ & $5.07 \pm 0.13$ \\
\hline Betung Bamboo & 10 & - & - \\
\hline \multirow[t]{5}{*}{ Shoots Sap } & 20 & - & - \\
\hline & 30 & - & $2.14 \pm 0.07$ \\
\hline & 40 & $3.51 \pm 0.32$ & $2.68 \pm 0.31$ \\
\hline & 50 & $4.53 \pm 0.26$ & $3.65 \pm 0.20$ \\
\hline & 60 & $5.65 \pm 0.05$ & $4.81 \pm 0.22$ \\
\hline $\begin{array}{l}\text { Positive control } \\
\text { (Amoxicillin } \\
25 \mu 1 / \text { disk) }\end{array}$ & - & $6.09 \pm 0.03$ & $5.65 \pm 0.05$ \\
\hline $\begin{array}{l}\text { Negative control } \\
\text { (Aquadest } \\
25 \mu 1 / \text { disk) }\end{array}$ & - & 0 & 0 \\
\hline
\end{tabular}

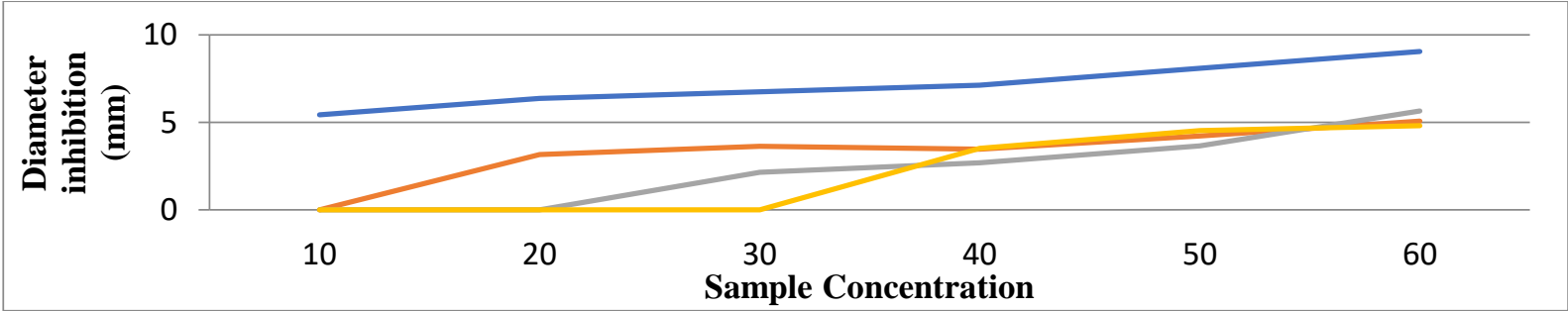

Figure 4. The graph between inhibition zone diameter and solution concentration. Kliebsiella pneumoniae; Pseudomonas aeruginosa 
The diameter of the inhibition zone in the sap of the Betung bamboo shoots began to appear at a concentration of $30 \%$, and the resulting average inhibition value was smaller than that of the ethanol extract. This can occur because the water content in the sap was higher than in the extract. The water content in the sample can affect the inhibition of bacteria because water is a medium for bacterial growth.

The greater the concentration, the greater the resulting inhibitory power because the more significant the concentration, the greater the active substance contained (21). Based on the Figure 4, it can be seen that the diameter of the inhibition zone is directly proportional to the total concentration of the solution. However, there may be a decrease in the area of the inhibition zone at a greater concentration. Research conducted by Ningtyas (21) stated that the diameter of the inhibition zone is not always directly proportional to the increase in antibacterial concentrations. This can occur due to differences in diffusion rates of antibacterial compounds on agar media and differences in the concentration of antibacterial compounds.

\section{Conclusion}

Qualitatively, the ethanol extract and sap of the bamboo shoots (Dendrocalamus asper) contain flavonoids, alkaloids, and saponins. The ethanol extract of bamboo betung has a moderate bacterial inhibitory power in Klebsiella pneumoniae and a weak Pseudomonas aeruginosa. Meanwhile, the sap of bamboo shoots has weak inhibition in the Klebsiella pneumoniae and Pseudomonas aeruginosa bacteria. It is necessary to research the activity test of the extract and sap of the shoots of bamboo betung against other bacteria, using other methods, and looking for other active compounds in the bamboo betung plant.

\section{Conflict of Interest}

All authors declare no conflicts of interest in this section.

\section{Refference}

1. Tarina N, Kusuma S. Deteksi Bakteri Klebsiella pneumonia. J Farmaka. 2017;15(2):119-26.

2. Mayasari E. Pseudomonas aeruginosa: karakteristik, infeksi dan penanganan. Medan: USU Repository; 2006.

3. Hidayat N, Masdiana C, Suhartini S. Mikrobiologi industri. Yogyakarta: CV Andi Offset; 2006.

4. Puri H. Rasayana: Ayurvedic herbs for longevity and rejuvenation. CRC Press; 2003.

5. Choudhury D, Sahu JK, Sharma GD. Value addition to bamboo shoots: A review. J Food Sci Technol. 2012;49(4):407-14.

6. Nofriati D, Ratima S. Kajian pascapanen dan manfaat rebung bagi kesehatan dalam menunjang keanekaragaman pangan yang berbasis pangan lokal. Jambi: Balai Pengkajian Teknologi Pertanian; 2019.

7. Alen Y, Agresa F, Yuliandra Y. Analisis kromatografi lapis tipis (KLT) dan aktivitas antihiperurisemia ekstrak rebung Schizostachyum brachycladum Kurz (Kurz) pada mencit putih jantan. J Sains Farm Klin. 2017;3(2):146-52.

8. Wulandari L. Kromatografi lapis tipis. 1st ed. Taman Kampus Presindo. Jember: PT. Taman Kampus Presindo; 2011. p. 20-26

9. Gandjar I, Rohman A. Kimia farmasi analisis. Yogyakarta: Pustaka Pelajar; 2007.

10. Susilowati S, Nuria M, Budiarti A. Identifikasi Kandungan Senyawa Kimia Ekstrak Etanol Herba Alfalfa (Medicago sativa, L). Media Farm Indones. 2014;9(2):732-42.

11. Kelly G. Quercetin. Altern Med Rev. 2011;16(2):172-94.

12. Widiasari N. Uji daya analgetik dan identifikasi kandungan kimia ekstrak etanol rimpang lempuyang wangi (Zingiber aromaticum Val.) secara Kromatografi Lapis Tipis. Surakarta: Universitas Sebelas Maret; 2015.

13. Depkes RI. Materia medika Indonesia jilid IV. Jakarta; 1995.

14. Soetarno S, Soediro I. Standarisasi mutu simplisia dan ekstrak bahan obat tradisional. In: Presidium Temu Ilmiah Nasional Bidang Farmasi. Depkes RI; 1997.

15. Kalita C, Ganguly M, Devi A. Evaluation of antioxidant capacity and antimicrobial properties of ethnic bambuseae species and identification of 
the active components. Int $\mathrm{J}$ Pharm Biol Arch. 2016;7(1):61-71.

16. Santoso S, Soemardini, Nugroho $P$. Efektifitas ekstrak etanol seledri (Apium graveolens) sebagai antifungal terhadap Candida albicans secara in vitro. $\mathbf{J}$ Penelit. 2010;

17. Prayoga E. Perbandingan efek ekstrak daun sirih hijau (Piper betle L.) dengan metode difusi disk dan sumuran terhadap pertumbuhan bakteri Staphylococcus aureus. Jakarta: Universitas Islam Negeri Syarif Hidayatullah; 2013.

18. Katzung B. Farmakologi dasar dan klinik III. Jakarta: Salemba Medika; 2004.

19. Pratiwi S. Mikrobiologi farmasi. Yogyakarta: Erlangga; 2008.

20. Davis W, Stout T. Disc plate method of microbiological antibiotic assay. Appl Microbiol. 1971;22(4):666-70.

21. Ningtyas A. Perbedaan konsentrasi dan uji aktivitas antibakteri ekstrak etanolik batang pisang kluthuk (Musa balbisiana Colla) terhadap Staphylococcus aureus dan Pseudomonas aeruginosa. Surakarta Universitas Sebelas Maret; 2012. 